\title{
17. SOME TRACE ELEMENTS IN BASALTS FROM LEG 34
}

\author{
J.R. Cann and Rosemary Heath, School of Environmental Sciences, \\ University of East Anglia, Norwich, NOR4 7TG, England
}

\section{INTRODUCTION}

Basalt samples from Holes 319, 319A, 320B, and Site 321 of Leg 34 of the Deep Sea Drilling Project were analyzed by X-ray fluorescence for the elements $\mathrm{K}, \mathrm{Ti}$, $\mathrm{Cr}, \mathrm{Cu}, \mathrm{Zn}, \mathrm{Rb}, \mathrm{Sr}, \mathrm{Y}, \mathrm{Zr}$, and $\mathrm{Nb}$ using the methods outlined by Cann (1970). The data obtained are presented in Table 1.

\section{TECTONIC ENVIRONMENT OF ERUPTION}

It is important to consider whether these basalts were erupted at a mid-ocean ridge crest or subsequent to the formation of the oceanic crust as the initial stages of seamount/ocean island volcanism. To decide this, the procedures of Pearce and Cann $(1971,1973)$ can be used. They divide basaltic volcanic rocks into five categories depending on their tectonic environment of eruption. These are OFB (erupted at normal mid-oceanic ridges); WPB (erupted within plates as seamounts/oceanic islands or as continental volcanoes, or at spreading plate boundaries of the Iceland or Afar type); and LKT, CAB, and SHO (erupted in volcanic arcs associated with a Benioff zone).

These categories can be distinguished using several trace elements in fresh basalts and the elements $\mathrm{Ti}, \mathrm{Zr}$, $\mathrm{Y}, \mathrm{Nb}$ in basalts that have suffered secondary processes such as weathering or low-grade metamorphism since their eruption, as these elements seem little affected by such processes (Cann, 1970). This discrimination is not always complete, but $\mathrm{Sr}$ (in basalts not too affected by secondary processes) may be used to supplement this information.

For their primary discrimination, Pearce and Cann (1973) used the triangular diagrams, Ti-Zr-Y and $\mathrm{Ti}-\mathrm{Zr}$ Sr. Figures 1 and 2 here are exactly analogous to these, transformed into cartesian coordinates. In Figure 1 ( $\mathrm{Ti} / \mathrm{Y}$ versus $\mathrm{Zr} / \mathrm{Y}$ ) the line separates the fields of WPB to the right from OFB, LKT, CAB, and SHO to the left. All of the Leg 34 samples plot in the field on the left, well clear of the dividing line, and are thus not of the WPB type.

In Figure 2 ( $\mathrm{Ti} / \mathrm{Sr}$ versus $\mathrm{Zr} / \mathrm{Sr}$ ) the line separates OFB to the right from LKT, CAB, and SHO to the left. Here all of the points lie well into the OFB field. Thus, the evidence from both diagrams is that these basalts are of the type erupted at normal mid-ocean ridges. This conclusion is also supported by the following trace element data. $\mathrm{Nb}$ is low, below $7 \mathrm{ppm}$ and $\mathrm{Y} / \mathrm{Nb}$ is high, greater than 6, both characteristics typical of OFB lavas. In addition, the $\mathrm{Ti} / \mathrm{Zr}$ ratio averages 95 , with a range from 84 to 117 , again a reoccurring characteristic of OFB lavas not shared by all other lava types.

Thus the trace element chemistry indicates strongly that these lavas are comparable in all their essential features with ocean floor basalts produced at mid-ocean ridge crests, and differ significantly from basalts of other tectonic environments, so that they do not, for example, represent the initial products of seamount or ocean island volcanism.

\section{EVOLUTION OF THE BASALT MAGMAS}

The measured trace elements are sensitive indicators of the evolutionary history of ocean floor basalts, and allow different stages in this history to be isolated, though work in this direction is still at an early stage. To help the discussion, the results have been plotted in Figure 3 where $\mathrm{Zr}$ has been used as a good indicator of the extent of evolution, and $\mathrm{Sr}, \mathrm{Y}, \mathrm{Nb}, \mathrm{Cr}$, and $\mathrm{Ti}$ have been plotted against it. The figures for $\mathrm{Cu}$ and $\mathrm{Zn}$ became available too late to be included here, but $\mathrm{Cu}$ shows a general decrease from $115 \mathrm{ppm}$ to $60 \mathrm{ppm}$ and less as $\mathrm{Zr}$ increases, while $\mathrm{Zn}$ shows a general increase from $70 \mathrm{ppm}$ to $120 \mathrm{ppm}$.

Although the basalts come from holes that are widely separated, they can be treated from the point of view of these trace elements as forming two petrogenetic groups, one comprising the top two samples from the basalt pile at Site 319, and the other comprising all of the rest of the samples. The second group, the $\mathrm{Zr}$-rich group with $\mathrm{Zr}$ always above $100 \mathrm{ppm}$, consists of all but the first two samples of Table 1, that is, the samples deeper than Core 1 of Hole 319A, both samples from Hole 320B, and all of the samples from Hole 321.

The Zr-rich group shows a trace element pattern consistent with Rayleigh-type (surface equilibrium) crystal fractionation from a single parental composition. Log$\log$ plots of $\mathrm{Ti}, \mathrm{Cr}, \mathrm{Cu}, \mathrm{Zn}, \mathrm{Sr}, \mathrm{Y}$, and $\mathrm{Nb}$ against $\mathrm{Zr}$ give approximately straight-line relationships, as the Rayleigh theory demands, and from the slopes of these lines, solid-liquid partition coefficients can be calculated, making the assumption that the partition coefficient for $\mathrm{Zr}$ is 0.25 . The results of the calculations of partition coefficient are: $\mathrm{Ti} 0.4, \mathrm{Cr} 2.5, \mathrm{Cu} 1.8, \mathrm{Zn} \mathrm{0.5}, \mathrm{Sr} 1.5, \mathrm{Y}$ 0.35 , and $\mathrm{Nb}$ about 0.05 (analytical error makes the last difficult to determine). These values are within expected limits, and reinforce the crystal fractionation model as a reasonable one. Comparison with other analyses of ocean floor basalts carried out in this laboratory (Cann, 1970 and unpublished) suggest that the parental magma concerned was not much more basic than the Hole 320B compositions, with a trace element composition close to: Ti, 9000; Cr, 500; Cu, 115; Zn, 77; Sr, 130; Y, 29; Zr, 90; and $\mathrm{Nb}, 2.5$ (all in ppm). Original $\mathrm{K}$ and $\mathrm{Rb}$ are difficult to determine for the Leg 34 basalts, because of secondary changes (see below), but it is likely that $\mathrm{K}$ in the parental magma was close to $1200 \mathrm{ppm}$ and $\mathrm{Rb}$ close to $1 \mathrm{ppm}$. Relative to this parent, the most fractionated 
TABLE 1

Trace Element Analyses of Leg 34 Basalts (ppm)

\begin{tabular}{lrrrrrrrrrr}
\hline $\begin{array}{c}\text { Sample } \\
\text { (Interval in cm) }\end{array}$ & $\mathrm{K}$ & $\mathrm{Ti}$ & $\mathrm{Cr}$ & $\mathrm{Cu}$ & $\mathrm{Zn}$ & $\mathrm{Rb}$ & $\mathrm{Sr}$ & $\mathrm{Y}$ & $\mathrm{Zr}$ & $\mathrm{Nb}$ \\
\hline 319-13-1, 108-111 & 1600 & 7750 & 286 & 110 & 77 & 3.5 & 101 & 26 & 66 & 0.5 \\
319A-1-1, 39-42 & 1400 & 6600 & 281 & 114 & 70 & 4.5 & 99 & 23 & 65 & 1.0 \\
319A-2-1, 146-149 & 1150 & 12000 & 245 & 74 & 93 & 4.0 & 117 & 39 & 131 & 4.0 \\
319A-3-5, 81-84 & 1000 & 12700 & 230 & 77 & 98 & 2.0 & 121 & 38 & 131 & 2.0 \\
319A-4-1, 141-144 & 850 & 11500 & 278 & 77 & 94 & 1.5 & 116 & 36 & 125 & 2.0 \\
319A-5-1, 72-75 & 900 & 10500 & 274 & 74 & 85 & 1.0 & 107 & 36 & 115 & 2.0 \\
319A-6-1, 142-145 & 3150 & 10900 & 281 & 88 & 96 & 7.0 & 111 & 36 & 116 & 0.5 \\
319A-7-1, 116-119 & 1500 & 10650 & 297 & 83 & 93 & 2.5 & 105 & 35 & 115 & 3.0 \\
320B-3-1, 117-120 & 2500 & 10850 & 322 & 97 & 93 & 5.0 & 134 & 33 & 108 & 2.5 \\
320B-4-1, 90-93 & 2200 & 8800 & 343 & 95 & 106 & 5.0 & 120 & 32 & 103 & 3.0 \\
321-13-4, 142-145 & 3100 & 17750 & 171 & 33 & 121 & 6.5 & 103 & 56 & 168 & 5.5 \\
321-14-1, 58-61 & 2200 & 14450 & 206 & 70 & 121 & 4.0 & 89 & 50 & 159 & 5.5 \\
321-14-2, 117-120 & 1250 & 13150 & 119 & 60 & 108 & 3.5 & 89 & 48 & 156 & 6.5 \\
321-14-3, 44-47 & 850 & 14000 & 137 & 62 & 112 & 0.5 & 87 & 46 & 155 & 4.5 \\
321-14-4, 45-48 & 1150 & 13300 & 119 & 66 & 109 & 2.0 & 89 & 48 & 157 & 5.0 \\
\hline
\end{tabular}

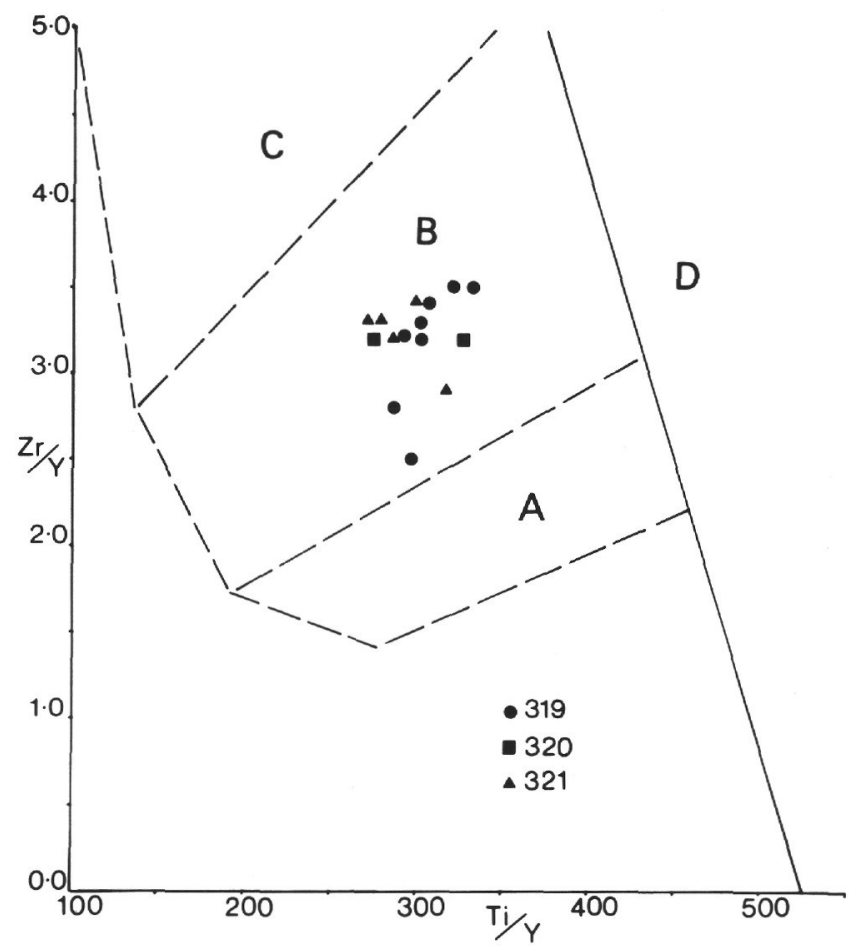

Figure 1. $Z r / Y$ plotted against Ti/Y for the Leg 34 basalts.

This is an adaptation of fig. 3 of Pearce and Cann (1973).

The fields have been drawn and lettered to correspond with that diagram. Fields $A$ and $C$ contain volcanic arc basalts, field $B$ ocean-floor basalts and volcanic arc basalts, and field $D$ WPB basalts (see text). The heavy line dividing $A, B$, and $C$ from $D$ has the equation: $0.00191 \mathrm{Ti} / Y+0.0565 \mathrm{Zr} / \mathrm{Y}=1$.

basalts of this group would require about $55 \%$ of solidification to be generated with these partition coeffi-

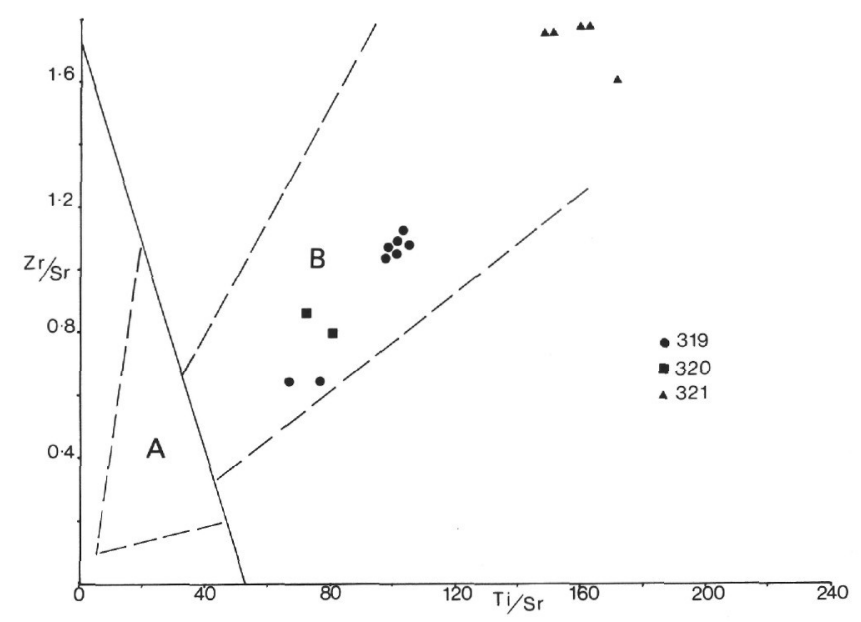

Figure 2. $\mathrm{Zr} / \mathrm{Sr}$ plotted against $\mathrm{Ti} / \mathrm{Sr}$ for the Leg 34 basalts. This is an adaptation of fig. 4 of Pearce and Cann (1973). Field A contains volcanic arc basalts and field $B$ ocean floor basalts (OFB). The heavy line dividing field $A$ from field $B$ has the equation: $0.0189 \mathrm{Ti} / \mathrm{Sr}+0.579$ $\mathrm{Zr} / \mathrm{Sr}=1$.

cients, a marked, but not extreme, degree of fractionation. Basalts derivable by crystal fractionation from an ocean floor basalt of about this trace element composition are not uncommon in other parts of the oceans, so that it is not an extreme coincidence that basalts from such widely separated holes should be relatable in this manner.

The variation of $\mathrm{Sr}$ in this group of basalts requires further comment. While the variation within the group as a whole corresponds to a partition coefficient of about 1.5, with the basalts from a single hole (most notably in the Hole 319A basalts of this group) the $\mathrm{Sr} / \mathrm{Zr}$ trend runs at a high angle to the overall trend. 


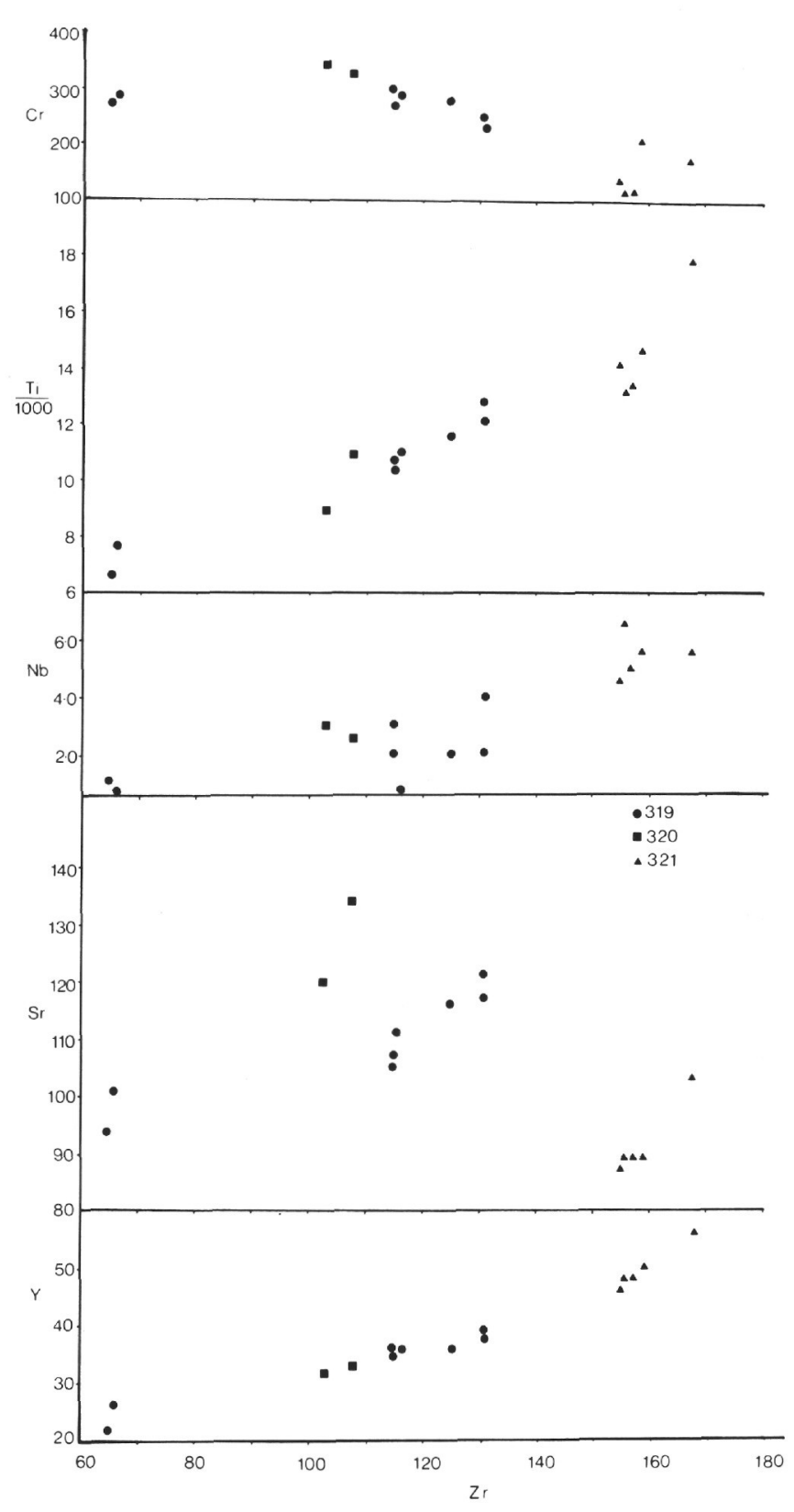

Figure 3. Variation diagram of some trace elements in the Leg 34 basalts, using $\mathrm{Zr}$ as an evolutionary indicator.

This direction corresponds to a calculated solid-liquid partition coefficient of about 0.35 , the same as that for Y. Such a trend must represent a late-stage fractionation effect, perhaps related to a suppression of nucleation of plagioclase (Gibb, 1974) or to other metastable crystallization processes within a single lava flow.

The Zr-poor group of basalts consists of only two samples and is not amenable to such detailed examination. However, the differences in trace element composition between these and the deeper samples at Site 319 show clearly that the Hole 319A basalt was derived from two separate sources. Examination of the $\mathrm{Cr}-\mathrm{Zr}$ plot in Figure 3 shows that these basalts cannot be related to those of the other group by shallow-depth crystal frac- tionation processes since this would entail either a partition coefficient for $\mathrm{Zr}$ greater than one, or a partition coefficient for $\mathrm{Cr}$ less than one. Either of these circumstances would be very unlikely in gabbroic crystal fractionation. Instead, the $\mathrm{Zr}$-poor group must represent products of a different batch of parental magma, depleted in $\mathrm{Zr}, \mathrm{Y}, \mathrm{Ti}$, and possibly $\mathrm{Sr}$ relative to the parent of the Zr-rich group. Such Zr-poor parental magmas seem less common among ocean floor basalts than the $\mathrm{Zr}$-rich ones, but reasonably close parallels can be found in basalts from the Gulf of Aden (Cann, 1970 and unpublished).

The relationship between these two classes of basalt magma must be sought in deeper level processes, perhaps in deep-level crystal fractionation, or in differences in melting processes. The two groups might be related, for example, by different degrees of partial melting, with the $\mathrm{Zr}$-poor group representing a two to three times greater fraction melted than the $\mathrm{Zr}$-rich group. Alternatively, the relationship may lie in variations in the incompatible element concentrations in the mantle, or perhaps in variations in the nature of the solid phases present in the residual solid after partial melting.

\section{WEATHERING}

Hart (1971) and Hart and Nalwalk (1970) have shown that $\mathrm{K}$ and $\mathrm{Rb}$ in ocean floor basalts are very sensitive to the degree of ocean floor weathering. In the Leg 34 samples, $\mathrm{K}$ and $\mathrm{Rb}$ show a very good correlation (Table 1) and $K / R b$ decreases as $K$ and $R b$ increase, ranging from about 1000 when $K$ is about 900 ppm to about 500 when $K$ is over $3000 \mathrm{ppm}$. This relationship is uncorrelated with the other trace element variations and must be ascribed to the effects of submarine weathering.

These effects clearly penetrate to the bottom of Hole $319 \mathrm{~A}$, but are irregular in their occurrence. Some samples, such as those with less than $1000 \mathrm{ppm}$ of $\mathrm{K}$, must be close to their eruption composition, while others, with a greater concentration of $\mathrm{K}$, are definitely weathered. The intensity of alteration must be related to the extent of contact with seawater and hence probably to the presence of fractures in the rock.

\section{ACKNOWLEDGMENTS}

We would like to thank Clive Winter and Janet Jones for help with the analyses and Julian Pearce for many useful discussions and for access to his unpublished Ph.D. thesis.

\section{REFERENCES}

Cann, J. R., 1970. Rb, Sr, Y, Zr and Nb in some ocean floor basaltic rocks: Earth Planet. Sci. Lett., v. 19, p. 7-11.

Gibb, F.G.F., 1974. Supercooling and the crystallization of plagioclase from a basaltic magma: Min. Mag., v. 39, p. 641-657.

Hart, S., 1971. K, Rb, Cs, Sr and Ba contents and $\mathrm{Sr}$ isotope ratios of ocean floor basalts: Phil. Trans. Roy. Soc. London, Ser. A, v. 268 , p. 573-587.

Hart, S.R. and Nalwark, A. J., 1970. K, Rb, Cs and Sr relationships in submarine basalts from the Puerto Rico trench: Geochem. Cosmochim. Acta, v. 34, p. 145-155.

Pearce, J. A. and Cann, J. R., 1971. Ophiolite origin investigated by discriminant analysis using $\mathrm{Ti}, \mathrm{Zr}$ and $\mathrm{Y}$ : Earth Planet. Sci. Lett., v. 12, p. 339-349. 
1973. Tectonic setting of basic volcanic rocks determined using trace element analyses: Earth Planet. Sci. Lett., v. 19 , p. $290-300$.
Thompson, G., Shido, F. and Miyashiro, A., 1972. Trace element distribution in fractionated oceanic basalts: Chem. Geol., v. 9, p. 89-97. 